\title{
Identifikasi Komoditas Unggulan Perikanan Tangkap Di Kabupaten Situbondo
}

\section{Identification of Leading Fishing Commodities in Situbondo}

\author{
Endang Suhesti ${ }^{1}$ \\ ${ }^{1}$ Program Studi Agribisnis, Fakultas Pertanian, Universitas Abdurachman Saleh Situbondo \\ Corresponding author; ndang_suhesti@unars.ac.id
}

Submited: 26 June 2021 Revised: 05 July 2021 Accepted: 22 July 2021 Publish: 31 July 2021

\begin{abstract}
Abstrak
Perairan di Provinsi Nusa Tenggara Barat (NTB) merupakan wilayah yang sangat potensial untuk pengembangan sektor perikanan tangkap karena perairan tersebut merupakan wilayah migrasi ikan. Potensi sumberdaya ikan yang tinggi di Kabupaten Situbondo seharusnya dapat dimanfaatkan secara optimal sehingga mendatangkan keuntungan bagi masyarakat nelayan. Strategi untuk mengoptimalkan pemanfaatan sumberdaya ikan yaitu dengan menentukan komoditas unggulannya. Metode dasar yang digunakan adalah metode deskriptif dengan pengambilan daerah penelitian secara purposive. Melalui observasi lapangan, wawancara, dan survei instansional maka didapatkan data-data penunjang yang dianalisis dengan metode analisis LQ (Location Quotient). Jenis data yang digunakan adalah data produksi komoditas sektor perikanan tangkap selama tahun 2018 hingga 2020. Komoditas pertanian unggulan yang diprioritaskan untuk dikembangkan di tiap kecamatan di Kabupaten Situbondo adalah ikan cucut di Kecamatan Banyuglugur, Ikan layang di Kecamatan Besuki dan Suboh, ikan manyung di Kecamatan Mlandingan dan Asembagus, ikan selar di Kecamatan Bungatan, udang di Kecamatan Kendit, ikan pari di Kecamatan Panarukan, lemuru di Kecamatan Mangaran ikan petek di Kecamatan Banyuputih, kepiting di Kecamatan Kapongan dan Arjasa. Komoditas unggulan dan paling banyak dihasilkan di Kabupaten Situbondo adalah kerapu, kembung dan kepiting.

Kata kunci : perikanan tangkap; komoditas unggulan Kabupaten Situbondo
\end{abstract}

\section{Abstract}

The waters in the Province of West Nusa Tenggara (NTB) are a very potential area for the development of the capture fisheries sector because these waters are fish migration areas. The high potential of fish resources in Situbondo Regency must be utilized optimally so as to provide benefits for the fishing community. The strategy to utilize fish resources is to determine the superior commodity. The basic method used is a descriptive method by taking the research area purposively. Through field observations, interviews, and institutional surveys, supporting data were obtained which were analyzed using the LQ (Location Quotient) analysis method. The type of data used is capture fisheries sector production data from 2018 to 2020. The priority agricultural commodities that are prioritized to be developed in each sub-district in Situbondo District are squid in Banyuglugur District, scad fish in Besuki and Suboh Districts, catfish in Mlandingan District and Asembagus, selar fish in Bungatan District, shrimp in Kendit District, stingray in Panarukan District, lemuru in Mangaran District, petek fish in Banyuputih District, crabs in Kapongan and Arjasa Districts. The leading and most produced commodities in Situbondo Regency are grouper, mackerel, and crab.

Keywords: fishing; Main commodity of Situbondo Regency

\section{PENDAHULUAN}

Perikanan termasuk dalam 5 subsektor pertanian yang juga turut berperan penting dalam pembangunan ekonomi di suatu daerah. Seiring dengan berlakunya otonomi daerah, maka setiap pemerintah daerah harus mengetahui potensi yang dimiliki oleh daerahnya sekaligus mampu menyelesaikan permalasahan yang dihadapi oleh pemerintah daerah yang berkaitan dengan kebijakan yang akan 
dibuat pemerintah agar tepat sasaran dan efektif.

$$
\text { Kabupaten Situbondo }
$$

merupakan bagian dari Provinsi Jawa Timur yang terletak di sepanjang pantai utara pulau jawa memanjang dari barat ke timur. Bagian sebelah barat berbatasan dengan Kabupaten Probolinggo, sebelah utara berbatasan langsung dengan selat madura, sebelah timur berbatasan dengan Kabupaten Banyuwangi dan sebelah selatan berbatasan Kabupaten Bondowoso.

Komoditas perikanan tangkap Kabupaten Situbondo bersumber dari 22 jenis Perikanan yang diusahakan di Kabupaten Situbondo yang terdiri dari ikan petek, beloso, bambangan, kerapu, kurisi, cucut, pari, bawal, layang, selar, belanak, teri, lemuru, kembung, tongkol, rajungan, kepiting, cumi cumi, manyung, layur, dan udang.

Potensi sumberdaya ikan yang tinggi di Kabupaten Situbondo seharusnya dapat dimanfaatkan secara optimal sehingga mendatangkan keuntungan bagi masyarakat nelayan. Salah satu strategi untuk mengoptimalkan pemanfaatan sumberdaya ikan yaitu dengan menentukan komoditas unggulannya. Analisis komoditas unggulan bertujuan untuk mengetahui efisiensi pengelolaan sumberdaya perikanan.

Hasil informasi mengenai komoditas sektor perikanan tangkap yang dapat diunggulkan di setiap kecamatan di Kabupaten Situbondo, diharapkan bisa untuk menentukan komoditas yang menjadi ciri khas di setiap kecamatan yang bersangkutan. Disamping itu bagi policy maker akan lebih mudah untuk menetapkan sasaran yang ingin dicapai dalam mengembangkan wilayah kecamatan, sehingga akan bisa mengurangi pemborosan anggaran. Selain itu, informasi ini juga akan bermanfaat bagi masyarakat di luar Kabupaten Situbondo untuk mendapatkan informasi tentang komoditas perikanan yang diinginkan di setiap kecamatan.

\section{METODOLOGI}

Daerah penelitian diambil secara sengaja (purposive) di Kabupaten Situbondo menggunakan data sekunder dengan mempertimbangkan bahwa salah satu potensi strategis Kabupaten Situbondo adalah subsektor perikanan dan kelautan yaitu perikanan tangkap. Perikanan tangkap didukung dengan garis pantai sepanjang $158 \mathrm{~km}$. Potensi sumberdaya alam perikanan dan kelautan belum 
dapat digali secara optimal, kardn@ : Indeks Location Quotien komoditas

minimnya usaha budidaya di laut, lahan budidaya air payau (tambak) dengan potensi lahan 913.000 Ha, (Renanti. H. F 2015).

Data yang diambil dalam penelitian ini berupa data sekunder, yaitu data dari Dinas Kelautan dan Perikanan Kabupaten Situbondo periode tahun 2018, 2019, dan tahun 2020. Data tersebut meliputi data produksi perikanan tangkap di 17 Kecamatan di Kabupaten Situbondo dan data produksi perikanan tangkap Kabupaten Situbondo. Analisis yang dipakai untuk menentukan komoditas unggulan di data produksi perikanan tangkap adalah analisis LQ (Location Quotient).

Analisis LQ adalah indeks perbandingan produksi suatu jenis ikan tertentu di 17 Kecamatan di Kabupaten Situbondo terhadap total produksi jenis ikan tertentu di Kabupaten Situbondo. Menurut pengertian lain, LQ digunakan untuk mengetahui sektor basis/potensial suatu wilayah tertentu (Daryanto \& Hufizrianda 2010). Besarnya LQ sepeti yang dikemukanan oleh Arsyad (2010), diperoleh persamaan sebagai berikut:

$$
L Q=\frac{v i / v t}{V I / V T}
$$

Keterangan : perikanan tangkap

: Produksi komoditas perikanan tangkap i pada tingkat kecamatan terpilih

vt :Total produksi komoditas perikanan tangkap di kecamatan terpilih

: Total produksi komoditas

VT : Total produksi seluruh komoditas perikanan tangkap

Nilai LQ > 1 menujukkan bahwa ikan jenis ke-i merupakan sektor basis dan memiliki daya saing tinggi. Nilai LQ $<1$ menujukkan bahwa ikan jenis ke-i bukan merupakan sektor basis, tidak memiliki daya saing, dan harus dipasok dari luar wilayah. Serta nilai LQ =1 menunjukkan bahwa jenis ikan ke-i bukan merupakan sektor basis, berdaya saing rendah dan hanya terdistribusi di wilayah lokal.

Pendekatan fokus produksi perikanan tangkap dengan LQ dilakukan menggunakan 2 kategori yaitu nilai LQ dan nilai pertumbuhan LQ. Kriteria scoring nilai LQ adalah sebagai berikut:

a) Nilai LQ diberi skor $=2$ jika LQ > 1 ;

b) Nilai LQ diberi skor $=1$ jika LQ = 1 ;

c) Nilai LQ diberi skor $=0$ jika LQ < 1.

Penentuan skor pertumbuhan LQ akan dilakukan menurut kriteria sebagai berikut: a) Jika pertumbuhan LQ positif, maka diberi skor $=2$ 
1) Jika pertumbuhan LQ tetap, maka diberi skor $=1$

2) Jika pertumbuhan LQ negatif maka diberi skor $=0$

Nilai penjumlahan tertinggi pada hasil pembobotan LQ merupakan komoditas unggulan yang dijadikan prioritas di Kabupaten Situbondo.

\section{HASIL DAN PEMBAHASAN}

Penetapan Komoditas Unggulan Berdasarkan Hasil Analisis $L Q$

Penetapan komoditas unggulan berdasarkan hasil analisis LQ, diperoleh indeks yang dapat membandingkan peranan jenis ikan tertentu di Kabupaten Situbondo. Nilai LQ yang lebih besar dari 1 merupakan komoditas sektor basis dan memiliki daya saing tinggi dibandingkan komoditas lainnya. Nilai LQ produksi perikanan tangkap di Kabupaten Situbondo Tahun 2018-2020 disajikan pada (Tabel 1). Populasi perikanan tangkap di kabupaten Situbondo dari tahun 2018-2020 terbesar, yaitu ikan tongkol kemudian ikan layang dan ikan kurisi. Jumlah ikan tongkol sebesar 2.585.960,00 ton (tahun 2018), 2.724.250,00 ton (tahun 2019) dan 3.310.950,00 ton (tahun 2020). Terbesar kedua adalah ikan layang, yang besarnya pada tahun 2018 adalah 2.095.050,00 ton, Tahun 2019 sebesar 2.225.820,00 ton dan pada tahun 2020 sebesar 2.308.490,00 ton. Sementara untuk ikan kurisi menempati urutan ke tiga, pada tahun 2018 sebesar 1.146.650,00 ton, Tahun 2019 sebesar 1.129.750,00 dan pada Tahun 2020 sebesar 1.031.860,00.

Berdasarkan data pada Tabel 1, diketahui bahwa terdapat 22 jenis komoditas perikanan tangkap di Kabupaten Situbondo pada tahun 2018, 2019 dan 2020. Bila dilihat dari nilai LQ pada tahun 2018, terdapat 10 jenis komoditas yang merupakan basis di Kabupaten Situbondo (nilai LQ > 1) dan sisanya sebesar 12 jenis merupakan komoditas non basis. Pada tahun 2019 jumlah komoditas basis Kabupaten Situbondo sebanyak 9 jenis dan sisanya sebanyak 13 jenis merupakan komoditas non basis. Sedangkan pada tahun 2020, jumlah komoditas basis di kabupaten Situbondo bertambah menjadi 13 jenis dan komoditas non basis berkurang menjadi 9 jenis.

Jika dilihat pada (Tabel 1), jenis komoditas sektor basis di kabupaten Situbondo hampir sama pada tiap-tiap tahun. Jenis hasil tangkapan yang memiliki nilai LQ yang tinggi antara lain ikan Manyung (Siluriformes), Cumi-cumi (Mastigoteuthis flammea), Bambangan / kakap merah (Lutjanus 
bitaeniatus), Kepiting (Callinectes

merah, kepiting dan kerapu merupakan sapidus) dan Kerapu (Epinephelus) . jenis hasil tangkapan yang paling Perolehan nilai LQ yang tinggi dipengaruhi oleh produksi jenis ikan di Kabupaten Situbondo setiap tahun. Ikan manyung, cumi-cumi, kakap banyak dihasilkan di beberapa kecamatan dan mampu menyumbang produksi ikan di Kabupaten Situbondo dan memiliki daya jual tinggi.

Tabel 1. Nilai Location Quotient (LQ) produksi perikanan tangkap Kabupaten Situbondo Tahun 20182020

\begin{tabular}{rlllrlrl}
\hline No & Jenis Ikan & \multicolumn{5}{c}{ LQ } \\
\cline { 3 - 7 } 1 & Petek & Th. 2018 & Sektor & Th. 2019 & Sektor & Th. 2020 & Sektor \\
2 & Beloso & 0,64 & Non Basis & 0,40 & Non Basis & 0,61 & Non Basis \\
3 & Bambangan & 1,36 & Basis & 0,95 & Basis & 1,31 & Basis \\
4 & Kerapu & 1,21 & Basis & 1,07 & Basis & 1,25 & Basis \\
5 & Kakap & 1,10 & Basis & 0,92 & Non Basis & 1,22 & Basis \\
6 & Kurisi & 1,21 & Basis & 0,91 & Non Basis & 1,11 & Basis \\
7 & Cucut & 0,90 & Non Basis & 0,00 & Non Basis & 1,09 & Basis \\
8 & Pari & 0,64 & Non Basis & 0,67 & Non Basis & 0,70 & Non Basis \\
9 & Bawal & 0,95 & Non Basis & 0,89 & Non Basis & 1,11 & Basis \\
10 & Layang & 0,93 & Non Basis & 0,99 & Non Basis & 0,86 & Non Basis \\
11 & Selar & 1,17 & Basis & 1,08 & Basis & 1,16 & Basis \\
12 & Belanak & 0,78 & Non Basis & 0,57 & Non Basis & 0,83 & Non Basis \\
13 & Teri & 0,78 & Non Basis & 0,84 & Non Basis & 0,84 & Non Basis \\
14 & Lemuru & 1,18 & Basis & 1,27 & Basis & 0,72 & Basis \\
15 & Kembung & 1,08 & Basis & 1,13 & Basis & 1,10 & Basis \\
16 & Tongkol & 0,98 & Non Basis & 1,05 & Basis & 0,93 & Non Basis \\
17 & Rajungan & 0,95 & Non Basis & 0,68 & Non Basis & 1,04 & Basis \\
18 & Kepiting & 1,20 & Basis & 1,21 & Basis & 1,27 & Basis \\
19 & Cumi-cumi & 1,47 & Basis & 1,18 & Basis & 1,29 & Basis \\
20 & Manyung & 2,39 & Basis & 2,26 & Basis & 1,40 & Basis \\
21 & Layur & 0,78 & Non Basis & 0,69 & Non Basis & 0,83 & Non Basis \\
22 & Udang & 0,91 & Non Basis & 0,89 & Non Basis & 1,13 & Non Basis \\
\hline
\end{tabular}

a. Penetapan Komoditas Unggulan Kecamatan

Pemanfaatan

potensi

sumberdaya dalam proses pembangunan daerah merupakan langkah awal yang sangat baik dan dapat memberikan dampak yang cukup luas terhadap pembangunan wilayah di Kabuapten Situbondo. Dalam hal ini sangat relevan apabila sektor pertanian seperti sub sektor perikanan dijadikan sebagai salah satu basis pengembangan ekonomi wilayah di Kabupaten Situbondo.

Komoditas perikanan akan memberikan suatu gambaran arah pengembangan bagi wilayah Kabupaten Situbondo, khususnya dalam hal mengoptimalkan keunggulan wilayah baik dari segi sumberdaya alam maupun 
sumberdaya manusia. Kabupaten Situbondo memiliki potensi pertanian yang mampu menunjang perekonomian khususnya pada sub sektor perikanan.

Prioritas pengembangan komoditas perikanan akan memberikan manfaat bagi masyarakat Kabupaten Situbondo. Pengembangkan komoditas perikanan tidak hanya usaha penagkapan ikan saja akan tetapi bisa melalui usaha penanganan pasca penangkapan seperti pengolahan ikan segar, pengolahan ikan asin, pengolahan ikan pindang, pengolahan ikan asap, tepung ikan dan terasi. Program ini mempengaruhi perluasan kebutuhan tenaga kerja dan peningkatan pendapatan masyarakat di wilayah Kabupaten Situbondo. Prioritas pengembangan komoditas perikanan untuk setiap kecamatan dapat dilihat dari hasil perhitungan analisa Location Quotient ( $L Q$ ) dengan melihat basis komoditas perikanan yang terdapat pada setiap kecamatan di Kabupaten Situbondo. Berikut akan disajikan diagram prioritas pengembangan perikanan tangkap pada 13 kecamatan (dari 17 kecamatan, 4 diantaranya tidak memeiliki pantai) di Kabupaten Situbondo.

Angka Location Quotient ( $L Q)$ untuk Kecamatan Banyuglugur menunjukkan angka prioritas untuk jenis ikan kembung, cucut, manyung, tongkol, layang dan teri. 6 jenis komoditas ini merupakan basis di Kabupaten Situbondo (nilai LQ > 1). Kecamatan Besuki memiliki prioritas 4 jenis ikan dengan LQ>1 yaitu ikan layang, teri, tongkol dan pari.

\section{BANYUGLUGUR}

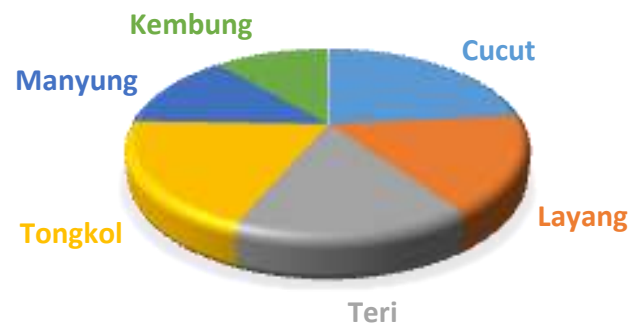

\section{BESUKI}

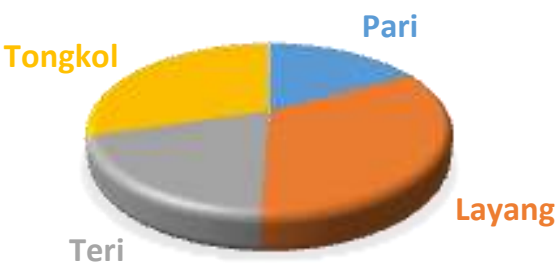

Gambar 1. Prioritas Komoditas Ikan Di Kecamatan Banyuglugur dan Besuki 


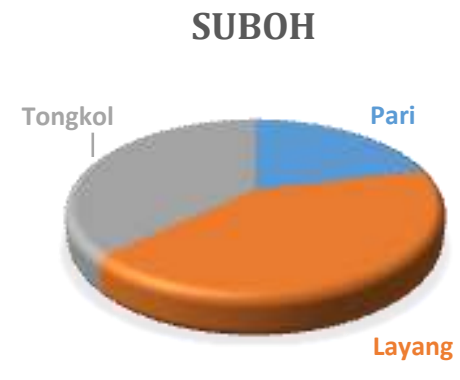

Gambar 2 menunjukkan prioritas yang dapat dikembangkan di Kecamatan Suboh hanya 3 jenis komoditas ikan, yaitu ikan layang, tongkol dan pari. Sementara di Kecamatan Mlandingan lebih banyak

Gambar 2. Prioritas Komoditas Ikan Di Kecamatan Besuki dan Mlandingan

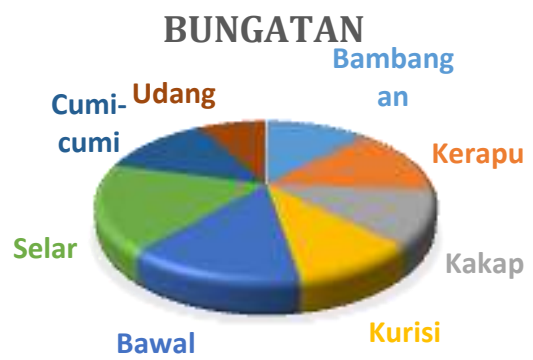

Bungatan dan Kendit memiliki jumlah basis yang lebih banyak dibandingkan kecamatan lainnya. Untuk Kecamatan Bungatan terdiri dari ikan bawal, selar, kurisi, kerapu, Gambar 4. Prioritas Komoditas Ikan

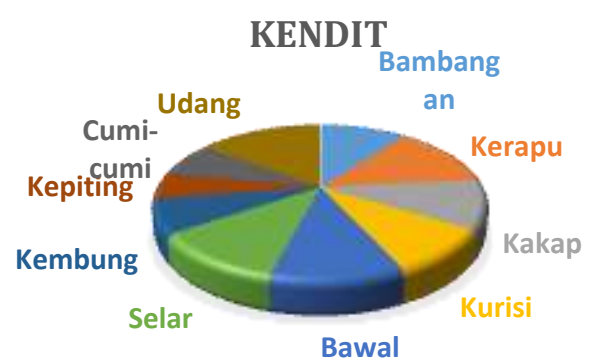

bambangan, kakap, cumi dan udang. Kecamatan Kendit terdiri ikan bawal, selar, kembung, kepiting, cumi, bambangan, kerapu, udang, kakap dan kurisi.

Di Kecamatan Mangaran dan Panarukan 


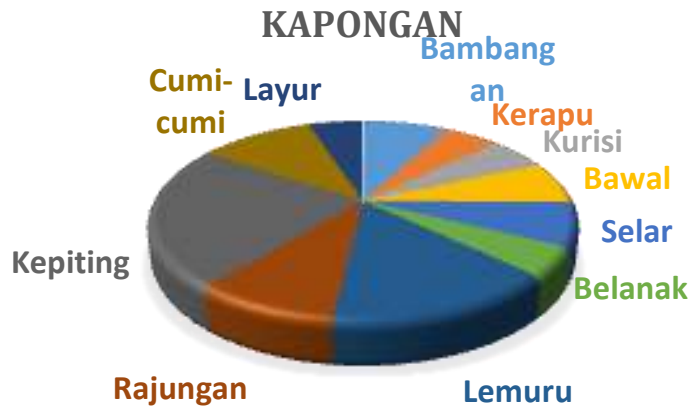

Kecamatan Mangaran memiliki lebih banyak ikan dengan kriteria basis, terdiri dari ikan lemuru, rajungan, kepiting, cumi, layur, udang, beloso, bambangan, kerapu, kakap, bawal,
ARJASA

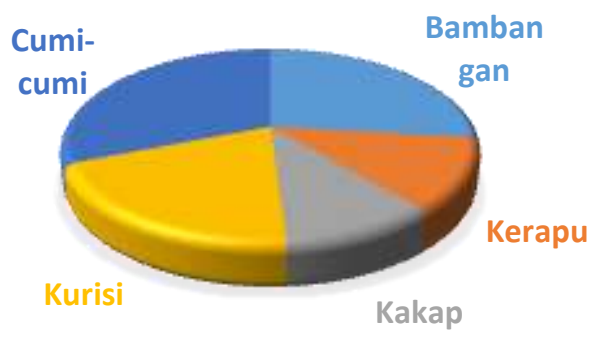

selar, belanak dan teri. Kecamatan Panarukan memliki 6 jenis ikan dengan kriteria basis, yaitu ikan pari, teri, rajungan, petek, kakap dan udang.

Gambar 5. Prioritas Komoditas Ikan Di Kecamatan Kapongan dan Arjasa

JANGKAR

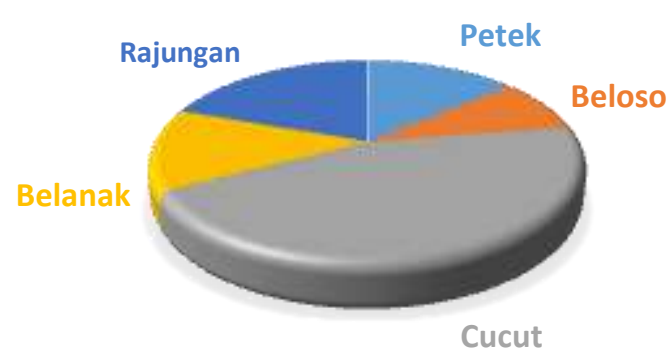

Kecamatan Kapongan yang bersebelahan dengan Kecamatan Mangaran juga memeiliki cukup banyak jenis ikan yang dapat diembangkan, diantaranya adalah ikan lemuru, rajungan, kepiting, cumi, layur, bambangan, kerapu, kurisi, bawal, selar, dan belanak. Sementara di Kecamatan Arjasa hanya ada 5 jenis ikan dengan LQ>1 yaitu ikan kakap, kurisi, cumi, bambangan dan kerapu. Ke wilayah timur yaitu Kecamatan Jangkar,

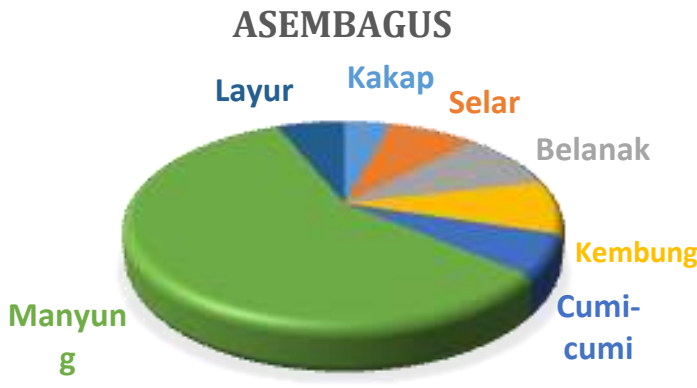

Asembagus dan Banyuputih, jumlah ikan dengan katagori basis semakin berkurang. Untuk Kecamatan Jangkar terdiri dari rajungan, belanak, petek dan beloso. Untuk Kecamatan Asembagus, manyung, layur, kakap, selar, belanak, kembung dan cumi. Sementara untuk Kecamatan Banyuputih yang terletak di wilayah paling timur Kabupaten Situbondo terdiri dari ikan layur, teri, petek, beloso, layang dan belanak. Komoditas ikan yang dapat 
dikembangkan pada masing-masing kecamatan berbeda. Ikan petek hanya dapat dikembangkan di Kecamatan Panarukan, Jangkar dan Banyuputih.

Komoditas ikan Beloso di Kecamatan Mangaran, Jangkar dan Banyuputih. Ikan Bambangan atau kakap merah dan kerapu memiliki potensi di Kecamatan Mlandingan, Bungatan, Kendit, Mangaran, Kaongan dan Arjasa. Ikan kakap memiliki penyebaran yang cukup luas di 7 kecamatan, yaitu Kecamatan Mlandingan, Bungatan, Kendit, Panarukan,Mangaran, Arjasa dan Asembagus.

Ikan Kurisi merupakan komoditas unggulan di Kecamatan Mlandingan, Bungatan, Kendit, Kapongan dan Arjasa. Untuk ikan cucut hanya ada di Kecamatan Banyuglugur dan Panarukan. Ikan pari hanya ada di 3 kecamatan, yaitu Kecamatan Besuki, Suboh dan Panarukan. Ikan bawal merupakan komoditas yang dapat dikembangkan di Kecamatan Mlandingan, Bungatan, Kendit, Mangaran dan Kapongan. Ikan layang cukup potensial di wilayah Kecatan Banyuglugur, Besuki, Suboh dan Banyuputih. Selar komoditas unggulan di wilayah Kecamatan Mlandingan, Bungatan, Kendit,
Mangaran, Kapongan dan Asembagus.

Belanak tersebar di wilayah Kecamatan Mangaran, Kapongan, Jangkar, Banyuputih dan Asembagus. Ikan teri komoditas basis di Kecamatan Banyuglugur, Besuki, Panarukan, Mangaran dan Banyuputih. Lemuru memiliki potensi hanya di Kecamatan Mangaran dan Kapongan. Ikan kembung basis di Kecamatan Banyuglugur, Mlandingan, Kendit dan Asembagus. Tongkol memiliki potensi di wilayah barat yaitu Kecamatan Banyuglugur, Besuki dan Suboh.

Sebaran Rajungan berda di wilayah Kecamatan Panarukan, Mangaran, Kapongan dan Jangkar. Kepiting merupakan komoditas unggulan di wilayah Kecamatan Mlandingan, Kendit, Mangaran, Kapongan, dan Arjasa. Cumi-cumi basis di Kecamatan Mlandingan, Bungatan, Kendit, Mangaran, Kapongan dan Asembagus. Manyung hanya berada di 3 kecamatan yaitu, Kecamatan Banyuglugur, Mlandingan dan Asembagus. Layur di 4 kecamatan yaitu, Kecamatan Mangaran, Kapongan, Banyuputih dan Asembagus. Dan udang menjadi komoditas yang memiliki prioritas dikembangkan di Kecamatan Mlandingan, Bungatan, 
Journal of Aquaculture Science

DOI: https://doi.org/10.31093/joas.v6i1IS.176
July 2021 Vol 6 Issue Spesial: 218-230

Online pada http://joas.co.id

Kendit, Panarukan dan Mangaran. dapat digambarkan pada tabel di bawah

Komoditas unggulan tiap kecamatan ini.

Tabel 2. Prioritas Pengembangan Komoditas Perikanan Tangkap di Kabupaten Situbondo

\begin{tabular}{|c|c|c|}
\hline \multirow[t]{2}{*}{ No } & \multirow[t]{2}{*}{ Kecamatan } & Prioritas Pengembangan Komoditas \\
\hline & & Perikanan Tangkap \\
\hline 1 & Banyuglugur & : kembung, cucut, manyung, tongkol, layang dan teri. \\
\hline 2 & Besuki & : layang, teri, tongkol dan pari. \\
\hline 3 & Jatibanteng & \\
\hline 4 & Sumbermalang & : \\
\hline 5 & Suboh & : layang, tongkol dan pari \\
\hline 6 & Mlandingan & $\begin{array}{l}\text { manyung, bawal, selar, kembung, kepiting, cumi-cumi, udang, bambangan, kerapu, } \\
\text { kakap, dan kurisi. }\end{array}$ \\
\hline 7 & Bungatan & : $\quad$ bawal, selar, kurisi, kerapu, bambangan, kakap, cumi dan udang \\
\hline 8 & Kendit & $\begin{array}{l}\text { : bawal, selar, kembung, kepiting, cumi, bambangan, kerapu, udang, kakap dan } \\
\text { kurisi. }\end{array}$ \\
\hline 9 & Panarukan & : pari, teri, rajungan, petek, kakap dan udang \\
\hline 10 & Situbondo & - \\
\hline 11 & Panji & - \\
\hline 12 & Mangaran & $\begin{array}{l}\text { lemuru, rajungan, kepiting, cumi, layur, udang, beloso, bambangan, kerapu, kakap, } \\
\text { bawal, selar, belanak dan teri }\end{array}$ \\
\hline 13 & Kapongan & $\begin{array}{l}\text { lemuru, rajungan, kepiting, cumi, layur, bambangan, kerapu, kurisi, bawal, selar, } \\
\text { dan belanak }\end{array}$ \\
\hline 14 & Arjasa & : kakap, kurisi, cumi, bambangan dan kerapu. \\
\hline 15 & Jangkar & : rajungan, belanak, petek dan beloso \\
\hline 16 & Asembagus & : manyung, layur, kakap, selar, belanak, kembung dan cumi \\
\hline 17 & Banyuputih & : layur, belanak, teri, petek, beloso, layang dan belanak \\
\hline
\end{tabular}

Sumber : Data Sekunder Diolah Tahun 2020

b. Penetapan Komoditas Unggulan Kabupaten

Analisis selanjutnya yang perlu dilakukan adalah dengan menghitung pertumbuhan nilai LQ dari tahun 2018 sampai 2020. Komoditas yang dapat dikatakan unggul akan memberikan nilai pertumbuhan yang positif sehingga berpengaruh terhadap kontribusi pada sektor perikanan dari tahun 2018 2020. Dari Tabel 3 di bawah ini diketahui bahwa pada periode tahun 2018-2019 dari 22 jenis komoditas unggulan yang diperhitungkan, hanya 7 jenis komoditas yang memiliki nilai pertumbuhan LQ positif. Sedangkan untuk periode Tahun 2019-2020 dari 22 jenis komoditas hanya 6 yang memiliki nilai pertumbuhan negatif berarti siasanya sebanyak 16 memberikan pertumbuhan positif. Pada Tabel 3 juga dapat dilihat bahwa jumlah komoditas unggulan periode tahun 2018-2019 yang memiliki nilai pertumbuhan LQ positif lebih sedikit dibandingkan periode tahun 2019-2020. Artinya produksi komoditas unggulan pada tahun 20182019 mengalami penurunan yang signifikan sehingga nilai pertumbuhan LQ-nya sebagian besar adalah negatif.

Tabel 3. Nilai pertumbuhan LQ Komoditas perikanan tangkap di Kabupaten Situbondo 


\begin{tabular}{|c|c|c|c|c|c|c|c|c|c|}
\hline \multirow[t]{2}{*}{ No } & \multirow[t]{2}{*}{ Jenis Ikan } & \multicolumn{3}{|c|}{ LQ } & \multirow{2}{*}{$\begin{array}{c}\text { Rata- } \\
\text { rata }\end{array}$} & \multicolumn{2}{|c|}{ Pertumbuhan } & \multirow{2}{*}{$\begin{array}{c}\text { Total } \\
\text { Growth }\end{array}$} & \multirow{2}{*}{$\begin{array}{c}\text { Skor } \\
\begin{array}{c}\text { Pertumbuha } \\
\text { n LQ }\end{array}\end{array}$} \\
\hline & & $\begin{array}{c}\text { Th. } \\
2018\end{array}$ & $\begin{array}{c}\text { Th. } \\
2019\end{array}$ & $\begin{array}{c}\text { Th. } \\
2020\end{array}$ & & $\begin{array}{c}2018- \\
2019\end{array}$ & $\begin{array}{c}2019- \\
2020\end{array}$ & & \\
\hline 1 & Petek & 0,64 & 0,40 & 0,61 & 0,55 & $-0,24$ & 0,21 & $-0,03$ & 0 \\
\hline 2 & Beloso & 0,81 & 0,62 & 0,88 & 0,77 & $-0,20$ & 0,26 & 0,07 & 2 \\
\hline 3 & Bambangan & 1,36 & 0,95 & 1,31 & 1,20 & $-0,41$ & 0,36 & $-0,05$ & 0 \\
\hline 4 & Kerapu & 1,21 & 1,07 & 1,25 & 1,18 & $-0,14$ & 0,18 & 0,04 & 2 \\
\hline 5 & Kakap & 1,10 & 0,92 & 1,22 & 1,08 & $-0,18$ & 0,30 & 0,12 & 2 \\
\hline 6 & Kurisi & 1,21 & 0,91 & 1,11 & 1,08 & $-0,30$ & 0,20 & $-0,10$ & 0 \\
\hline 7 & Cucut & 0,90 & 0,00 & 1,09 & 0,66 & $-0,90$ & 1,09 & 0,19 & 2 \\
\hline 8 & Pari & 0,64 & 0,67 & 0,70 & 0,67 & 0,03 & 0,03 & 0,06 & 2 \\
\hline 9 & Bawal & 0,95 & 0,89 & 1,11 & 0,98 & $-0,06$ & 0,22 & 0,16 & 2 \\
\hline 10 & Layang & 0,93 & 0,99 & 0,86 & 0,92 & 0,06 & $-0,13$ & $-0,07$ & 0 \\
\hline 11 & Selar & 1,17 & 1,08 & 1,16 & 1,14 & $-0,09$ & 0,09 & $-0,01$ & 0 \\
\hline 12 & Belanak & 0,78 & 0,57 & 0,83 & 0,72 & $-0,21$ & 0,26 & 0,05 & 2 \\
\hline 13 & Teri & 0,78 & 0,84 & 0,84 & 0,82 & 0,06 & $-0,01$ & 0,06 & 2 \\
\hline 14 & Lemuru & 1,18 & 1,27 & 0,72 & 1,06 & 0,09 & $-0,55$ & $-0,46$ & 0 \\
\hline 15 & Kembung & 1,08 & 1,13 & 1,10 & 1,10 & 0,05 & $-0,03$ & 0,02 & 2 \\
\hline 16 & Tongkol & 0,98 & 1,05 & 0,93 & 0,99 & 0,07 & $-0,12$ & $-0,04$ & 0 \\
\hline 17 & Rajungan & 0,95 & 0,68 & 1,04 & 0,89 & $-0,27$ & 0,36 & 0,09 & 2 \\
\hline 18 & Kepiting & 1,20 & 1,21 & 1,27 & 1,23 & 0,02 & 0,06 & 0,08 & 2 \\
\hline 19 & Cumi-cumi & 1,47 & 1,18 & 1,29 & 1,31 & $-0,29$ & 0,12 & $-0,18$ & 0 \\
\hline 20 & Manyung & 2,39 & 2,26 & 1,40 & 2,02 & $-0,13$ & $-0,86$ & $-1,00$ & 0 \\
\hline 21 & Layur & 0,78 & 0,69 & 0,83 & 0,77 & $-0,09$ & 0,14 & 0,05 & 2 \\
\hline 22 & Udang & 0,91 & 0,89 & 1,13 & 0,98 & $-0,01$ & 0,23 & 0,22 & 2 \\
\hline
\end{tabular}

Perbedaan hasil analisis ini disebabkan karena perbedaan metode analisis data yang dilakukan. Analisis menggunakan Location Quotient (LQ) sangat bergantung pada besarnya volume produksi suatu komoditas (Kohar 2012). Komoditas yang memiliki nilai jual tinggi tidak akan menjadi komoditas unggulan apabila jumlah produksinya rendah. Volume produksi yang tinggi dari tahun ke tahun akan menyebabkan komoditas tersebut menjadi unggulan suatu daerah. Diagram pertumbuhan LQ dapat dilihat pada Gambar 8, dimana nilai pertumbuhan yang positif menunjukkan bahwa terjadi peningkatan produksi per tahunnya. Beberapa komoditas ikan yang memiliki skor 2 terjadi pada jenis komoditas udang, ikan cucut, bawal, kakap, rajungan, kepiting, beloso, teri, pari, layur, belanak, kerapu dan kembung. Ikan-ikan tersebut merupakan komoditas yang paling tinggi jumlah produksinya dibandingkan dengan komoditas lainnya di Kabupaten Situbondo. 
Total

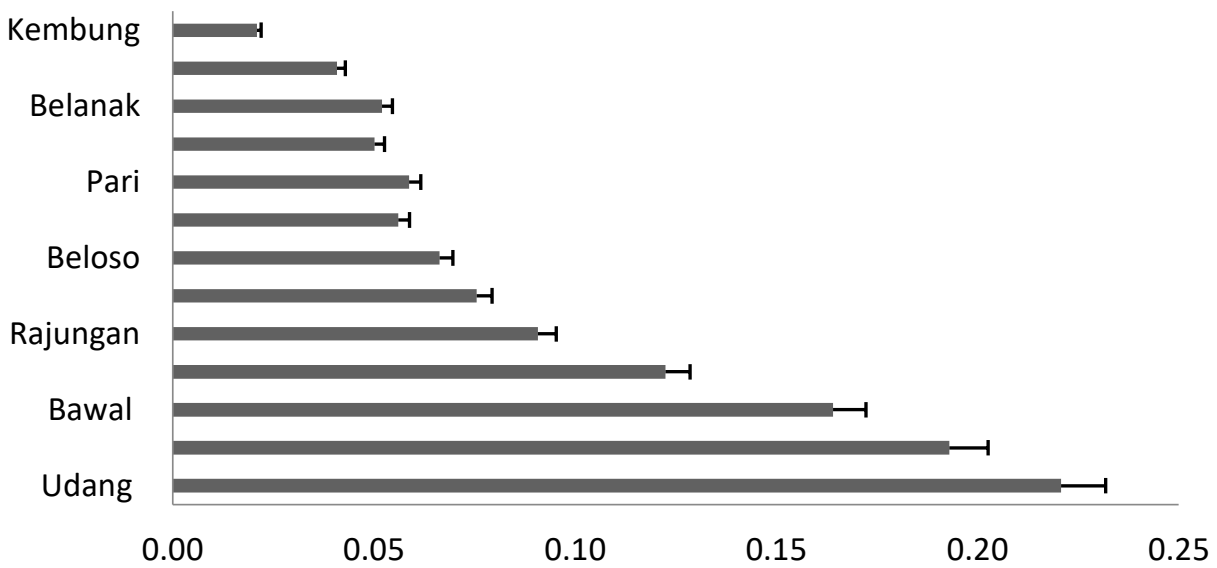

Gambar 8. Nilai Pertumbuhan LQ Komoditas Unggulan di Kabupaten Situbondo

Komoditas unggulan di pemberian skor ini yaitu; bila nilai total

Kabupaten tidak hanya dapat dilihat pertumbuhan LQ positif maka akan dari nilai pertumbuhan LQ tetapi masih diberikan skor 2, sedangkan bila total perlu dilakukan perhitungan nilai pertumbuhan negatif maka akan keseluruhan skor dari masing-masing diberikan skor 0 , dan bila komoditas tiap tahun. Analisis pertumbuhannya tetap maka akan selanjutnya adalah pemberian skor diberikan skor 1. Hasil pemberian bobot pertumbuhan LQ. Analisis ini masih untuk setiap komoditas akan digunakan dilakukan terhadap 22 jenis komoditas untuk menentukan jenis komoditas yang memiliki nilai LQ > 1 . Kriteria unggulan di Kabupaten Situbondo.

Tabel 4. Penentuan komoditas unggulan perikanan tangkap di Kabupaten Situbondo

\begin{tabular}{|c|c|c|c|c|c|c|c|}
\hline \multirow[t]{3}{*}{ No } & \multirow[t]{3}{*}{ Jenis Ikan } & Total & Skor & \multicolumn{3}{|c|}{ LQ } & Total \\
\hline & & Growth & Pertumbuhan & & & & Skor \\
\hline & & & LQ & 2018 & 2019 & 2020 & \\
\hline 1 & Petek & $-0,03$ & 0 & 0 & 0 & 0 & 0 \\
\hline 2 & Beloso & 0,07 & 2 & 0 & 0 & 0 & 2 \\
\hline 3 & Bambangan & $-0,05$ & 0 & 2 & 0 & 2 & 4 \\
\hline 4 & Kerapu & 0,04 & 2 & 2 & 2 & 2 & 8 \\
\hline 5 & Kakap & 0,12 & 2 & 2 & 0 & 2 & 6 \\
\hline 6 & Kurisi & $-0,10$ & 0 & 2 & 0 & 0 & 2 \\
\hline 7 & Cucut & 0,19 & 2 & 0 & 0 & 0 & 2 \\
\hline 8 & Pari & 0,06 & 2 & 0 & 0 & 0 & 2 \\
\hline 9 & Bawal & 0,16 & 2 & 0 & 0 & 0 & 2 \\
\hline 10 & Layang & $-0,07$ & 0 & 0 & 0 & 0 & 0 \\
\hline 11 & Selar & $-0,01$ & 0 & 2 & 2 & 2 & 6 \\
\hline 12 & Belanak & 0,05 & 2 & 0 & 0 & 0 & 2 \\
\hline 13 & Teri & 0,06 & 2 & 0 & 0 & 0 & 2 \\
\hline 14 & Lemuru & $-0,46$ & 0 & 2 & 2 & 2 & 6 \\
\hline 15 & Kembung & 0,02 & 2 & 2 & 2 & 2 & 8 \\
\hline 16 & Tongkol & $-0,04$ & 0 & 0 & 2 & 2 & 4 \\
\hline
\end{tabular}




\begin{tabular}{llrlllll}
\hline 17 & Rajungan & 0,09 & 2 & 0 & 0 & 0 & 2 \\
18 & Kepiting & 0,08 & 2 & 2 & 2 & 2 & 8 \\
19 & Cumi-cumi & $-0,18$ & 0 & 2 & 2 & 2 & 6 \\
20 & Manyung & $-1,00$ & 0 & 2 & 2 & 2 & 6 \\
21 & Layur & 0,05 & 2 & 0 & 0 & 0 & 2 \\
22 & Udang & 0,22 & 2 & 0 & 0 & 0 & 2 \\
\hline
\end{tabular}

Berdasarkan hasil skor penilaian LQ dan skor pertumbuhan LQ terhadap 22 jenis komoditas ikan basis di Kabupaten Situbondo (Tabel 4), maka dapat ditentukan jenis komoditas unggulannya menurut aspek produksi yaitu ikan kerapu, ikan kembung dan kepiting. Sebanyak 3 jenis komoditas ini memiliki kontribusi terhadap produksi hasil tangkapan yang tinggi bila dibandingkan dengan ikan sejenisnya di Kabupaten Situbondo.

\section{KESIMPULAN}

Berdasarkan hasil yang diperoleh, maka dapat ditarik kesimpulan sebagai berikut : jenis hasil tangkapan yang memiliki nilai LQ yang tinggi antara lain ikan cucut di Kecamatan Banyuglugur, Ikan layang di Kecamatan Besuki dan Suboh, ikan manyung di Kecamatan Mlandingan dan Asembagus, ikan selar di Kecamatan Bungatan, udang di Kecamatan Kendit, ikan pari di Kecamatan Panarukan, lemuru di Kecamatan Mangaran ikan petek di Kecamatan Banyuputih, kepiting di Kecamatan Kapongan dan Arjasa.
Ikan-ikan tersebut merupakan komoditas basis yang paling banyak dihasilkan di Kabupaten Situbondo.

Jenis komoditas unggulan Kabupaten Situbondo berdasarakan skor pertumbuhan LQ yaitu ikan kerapu, ikan kembung dan kepiting. Komoditas ini memiliki kontribusi terhadap produksi hasil tangkapan yang tinggi setiap tahun bila dibandingkan dengan ikan yang lain di Kabupaten Situbondo.

\section{DAFTAR PUSTAKA}

Arsyad, L. 2010. Pengantar Perencanaan dan Pembangunan Ekonomi Daerah. STIM YKPN. Yogyakarta.

Dinas Kelautan dan Perikanan Kabupaten Situbondo. (2020). Pemerintah Kabupaten Situbondo. (tidak dipublikasikan)

Kohar, A., \& Paramartha, D. (2012). Analisis Komoditas Unggulan Perikanan Tangkap di Kabupaten Rembang. Jurnal Harpodon Borneo, 5(2): 161171.

Renanti, H. F. 2015. Analisis Pengembangan Usaha Hatchery Skala Rumah Tangga Kerapu di Kecamatan Bungatan Kabupaten Situbondo, Jurusan Magister Ilmu Ekonomi. Fakultas Ekonomi Universitas Jember. Jember.

Tarigan, R. 2002. Perencanaan Pembangunan Wilayah Pendekatan Ekonomi dan Ruang. Departemen Pendidikan Nasional. Medan. 